потенциалу социальных сетей свидетельствует об их стремлении к учету в своей деятельности по сути дела безграничных возможностей сетевых технологий и обеспечению минимизации «заградительных мер» технического порядка со стороны официальных государственных структур [5, с. 154]. Резюмируя изложенное, необходимо отметить следующее: во-первых, современный уровень развития информационного общества предъявляет существенно возросшие требования к уровню транспарентности процесса формирования представительных органов власти и неукоснительного соблюдения служащими правоохранительных структур предписанных им канонов законности; во-вторых, гарантией устойчивого развития экономики и поддержания в стране должного общественного порядка выступает приверженность власти с безусловному укреплению демократических начал в обществе.

1. Бумажная агитация // Телеграмм-канал «Беларуский Телеграм». - URL: https:/peramen.org/ (дата обращения: 03.01.2021)

2. Народно-освободительный фронт «Внуки партизан» // Телеграмм-канал «Внуки партизан». - URL: https://telegra.ph/Biblioteka-Partizan-12-07 (11.01.2021)

3. План Победы. Информационный фронт // Телеграмм-канал «Беларусь головного мозга». - URL: https://t.me/belamova (дата обращения: 18.01.2021)

4. Чек-лист Победы // Телеграмм-канал «Листовки 97 \%». - URL: https://t.me/listovki_97 (дата обращения: 15.01.2021)

5. Чимаров С.Ю. Тактика онлайн-мобилизации протестного движения в Республике Беларусь // Тенденции развития науки и образования. - 2020. - № 68-7. - С. 151-155.

\title{
Чимаров С.Ю., Паншина С.В. \\ Актуальные вопросы соблюдения прав человека в условиях дигитализации социального взаимодействия: на примере функционирования социальных сетей
}

Санкт-Петербургский университет МВД России

(Россия, Санкт-Петербург)

doi: $10.18411 / \mathrm{lj}-02-2021-19$

idsp: ljournal-02-2021-19

\section{Аннотация}

В статье представлен анализ правовых новелл, касающихся ряда ограничений и запретов в части распространения информации по сети «Интернет». Выявляя актуальность соблюдения в процессе онлайн-коммуникации прав человека и уточняя понятие социальных сетей, авторы акцентируют внимание на важности учета динамики развития современного информационного общества в интересах обеспечения гармонии между дозволенным и запрещенным.

Ключевые слова: права человека, правовая новелла, цифровая бдительность, социальная сеть, сетевое пространство, онлайн-коммуникация, цифровые технологии.

\section{Abstract}

The article presents an analysis of legal novels concerning a number of restrictions and prohibitions in terms of the dissemination of information on the «Internet». Revealing the relevance of observing human rights in the process of online communication and clarifying the concept of social networks, the authors emphasize the importance of taking into account the dynamics of the development of the modern information society in the interests of ensuring harmony between what is permitted and what is prohibited.

Keywords: human rights, legal novel, digital vigilance, social networking, networking space, online communication, digital technologies. 
Проблема сохранения баланса между соблюдением прав человека в цифровой среде и допустимым пределом ограничения этих прав является одной из ключевых для области правозащитной деятельности. Либеральные ценности неотчуждаемых прав человека, правовой защищенности личности, дихотомии права и закона в значительной степени определяют характер демократического развития общества. Феномен дигитализации общественных отношений в эпоху Шестого технологического уклада предъявляет новые требования к решению проблемы верховенства права, обращенной к свободе слова, защите персональных данных национальной безопасности, противодействию киберпреступности и т.п. Существующие онлайн-схемы политического экстремизма, вторжение в личную жизнь человека, формирования онлайн-вариаций мошенничества, террора, разжигание ненависти к людям иной расы и веры, определяют необходимость адекватного и оперативного решения вопроса защиты прав человека в условиях нарождающегося господства цифровых технологий [3, с. 27]. Обращенные к «Интернет»-пространству вообще, указанные выводы имеют первенствующее отношение применительно к области действия социальных сетей, в частности. В современной науке о медиапространстве и различных источниках по информационному праву презентуется множество вариаций относительно определения социальной сети. По нашему мнению, особого внимания заслуживает понятие «социальная сеть», сформулированное специалистами американской компании «Dell EMC», одной из крупнейших в мире корпораций по разработке и производству систем хранения данных и программного обеспечения для управления информационными инфраструктурами (штаб-квартира в г. Хопкинтон, штат Массачусетс-США): «Социальная сеть-это любой инструмент или сервис, который применяется для общения в «Интернете» на основе пяти принципов: 1) дружелюбия и общительности; 2) защиты информации; 3) ясности и честности; 4) соблюдения законов и кодекса корпоративной этики; 5) ответственности. Этот термин относится не только к общеизвестным сетям, таким как «Facebook», «Twitter» и «WeChat», но и к другим платформам, включающим возможность общения пользователей, которые вы бы не назвали социальными сетями. Такие платформы, как «YouTube», «Flickr», блоги и «wiki-энциклопедии», тоже являются социальными сетями» [2]. Выявляя миссию социальных сетей, следует заметить, что их основное функциональное и общественное предназначение заключается: во-первых, в предоставлении возможности общения (налаживание рабочих и личных контактов); во-вторых, в поощрении цифрового обмена информацией и цифрового социального взаимодействия. Указанные аспекты, несомненно, свидетельствуют в пользу очевидных преимуществ отмеченной парадигмы социального взаимодействия в ее дигитальной форме. Вместе с тем, при нарушении канонов цифровой бдительности и заповедей цифрового обмена появляются эвентуальные угрозы и риски при апеллировании к потенциалу социальных сетей. В частности, следует учитывать то обстоятельство, что любая информация, размещенная в социальных сетях, может выйти из-под контроля, независимо от настроек конфиденциальности. Указанный тезис соответствует суждению отечественного юриста П.А. Астапенко относительно того, что масштаб воздействия «Интернета» в части прав человека свидетельствует об институциональной уязвимости прав и свобод в эпоху онлайн-сетевого взаимодействия [1, с. 16].

В целях соблюдения прав человека, пребывающего в системе координат дигитального социального взаимодействия, национальное законодательство различных государств закрепляет ряд ограничительных требований, регламентирующих циркуляцию контента распространяемой по социальным сетям информации. Иллюстрацией к отмеченному служат правовые новеллы в части особенностей распространения информации в социальных сетях, закрепленные в ст. 10.6 Федерального закона от 27 июля 2006 г. № 149-Ф3 «Об информации, информационных технологиях и о защите информации», введенной Федеральным законом от 30 декабря 
2020 г. № 530-Ф3. В частности, владелец социальной сети (владелец сайта, страницы сайта в сети «Интернет», информационной системы, программы для ЭВМ, которые предназначены и используются их пользователями для предоставления и распространения посредством созданных ими персональных страниц информации на государственном языке РФ, государственных языках республик в составе РФ или иных языках народов Российской Федерации, на которых может распространяться реклама, направленная на привлечение внимания потребителей, и доступ к которым в течение суток составляет более 500 тыс. пользователей сети «Интернет», находящихся на территории РФ), обязан соблюдать следующие требования законодательства РФ:

1. Не допускать использование в социальной сети в целях совершения уголовно наказуемых деяний, разглашения сведений, составляющих государственную или иную специально охраняемую законом тайну, распространения материалов, содержащих публичные призывы к осуществлению террористической деятельности или публично оправдывающих терроризм, других экстремистских материалов, а также материалов, пропагандирующих порнографию, культ насилия и жестокости, и материалов, содержащих нецензурную брань;

2. Не допускать распространение информации с целью дискриминации граждан по признакам пола, возраста, расовой или национальной принадлежности, языка, отношения к религии, профессии, места жительства и работы, а также их политических убеждений;

3. Соблюдать запреты и ограничения, предусмотренные законодательством РФ о референдуме и законодательством РФ о выборах;

4. Соблюдать права и законные интересы граждан и организаций, в том числе честь, достоинство и деловую репутацию граждан, деловую репутацию организаций;

5. Осуществлять мониторинг социальной сети в целях выявления: а) материалов с порнографическими изображениями несовершеннолетних и объявлений о привлечении несовершеннолетних в качестве исполнителей для участия в зрелищных мероприятиях порнографического характера; б) информации о способах, методах разработки, изготовления и использования наркотических средств, психотропных веществ и их прекурсоров, новых потенциально опасных психоактивных веществ, местах их приобретения, способах и местах культивирования наркосодержащих растений; в) информации о способах совершения самоубийства, а также призывов к совершению самоубийства; г) информации, нарушающей требования федерального законодательства относительно запрета деятельности по организации и проведению азартных игр и лотерей с использованием сети «Интернет» и иных средств связи; д) информации, содержащей предложения о розничной продаже дистанционным способом алкогольной продукции, спиртосодержащей пищевой продукции, этилового спирта, спиртосодержащей непищевой продукции, розничная продажа которой ограничена или запрещена законодательством о государственном регулировании производства и оборота этилового спирта, алкогольной и спиртосодержащей продукции и об ограничении потребления (распития) алкогольной продукции; е) информации, направленной на склонение или иное вовлечение несовершеннолетних в совершение противоправных действий, представляющих угрозу для их жизни и здоровья либо для жизни и здоровья иных лиц; ж) информации, выражающей в неприличной форме, которая оскорбляет человеческое достоинство и общественную нравственность, явное неуважение к обществу, государству, официальным государственным символам РФ, Конституции РФ или органам, осуществляющим государственную власть в РФ; з) информации, содержащей призывы к массовым беспорядкам, осуществлению экстремистской деятельности, участию в массовых (публичных) мероприятиях, проводимых с нарушением установленного порядка, недостоверной общественно значимой информации, распространяемой под видом 
достоверных сообщений, которая создает угрозу причинения вреда жизни и здоровью граждан, имуществу, угрозу массового нарушения общественного порядка и общественной безопасности либо угрозу создания помех функционированию или прекращения функционирования объектов жизнеобеспечения, транспортной или социальной инфраструктуры, кредитных организаций, объектов энергетики, промышленности или связи, информационных материалов иностранной или международной неправительственной организации, деятельность которой признана нежелательной на территории РФ в соответствии с Федеральным законом от 28 декабря 2012 г. № 272-Ф3 «О мерах воздействия на лиц, причастных к нарушениям основополагающих прав и свобод человека, прав и свобод граждан Российской Федерации», сведений, позволяющих получить доступ к указанным информации или материалам. Резюмируя изложенное, необходимо сформулировать следующие выводы: во-первых; современная архитектура социального взаимодействия посредством компонентной базы онлайн-сетевых приемов не подлежит ее переводу в «прокрустово ложе» прежних представлений о сущности процесса коммуникации; во-вторых; потенциал современных социальных сетей не противоречит принципу незыблемости прав и свобод человека, условием реализации которого выступает обязательное соблюдение канонов цифровой бдительности и правил сетевого общения; в-третьих, национально-государственная модель правового регулирования онлайн-коммуникации в формате «Интернет»-пространства, ограждая человека от неправомерного вмешательства посторонних лиц в область его личной жизни, безусловно должна быть ориентирована и на учет интересов общества, с позиции признания особой значимости актуальных вопросов общественной и национальной безопасности.

$$
\text { *** }
$$

1. Астапенко П.Н. Интернет, социальные сети и права человека // Закон и право. - 2019. - № 10. - С. $15-21$.

2. Глобальная политика в отношении социальных сетей. 1 июня 2017 г. // Официальный сайт корпорации «Dell». - URL: https://www.dell.com/learn/ru/ru/rucorp1/corp-comm/social-media-policy (дата обращения: 02.02.2021)

3. Чимаров С.Ю. Юридизация стратегического планирования в Российской Федерации защиты прав человека цифровой эпохи // Современное общество и право. - 2018. - № 1 (32). - С. 26-32. 